TOMASZ WICHERKIEWICZ

(iD https://orcid.org/0000-0003-3163-0454

Uniwersytet Hokkaido

Sapporo

Uniwersytet im. A. Mickiewicza

Poznań

\title{
Języki regionalne w Polsce na tle europejskim \\ - z perspektywy glottopolitycznej i ekolingwistycznej
}

Regional languages in Poland against a European background

- from the point of view of glottopolitics and ecolinguistics

\begin{abstract}
The paper discusses and analyses the situation of regional languages in Poland against the background of phenomena taking place in Europe. The phenomena discussed include language extinction, language revival and raising the prestige of linguistic varieties generally considered inferior to recognised languages, i.e. state, national or official ones.
\end{abstract}

Key words: regional languages, glottopolitics, ecolinguistics, language extinction, language revival

\section{Wprowadzenie}

Wraz z nasileniem trendów globalizacyjnych w świecie przełomu XX i XXI w., zarówno repertorium, jak i zakres dywersyfikacji odmian językowych ulega obecnie znacznym zmianom o dynamice przeciwkierunkowych tendencji. Z jednej strony we wszystkich regionach świata obserwuje się gwałtownie przyspieszające procesy wymierania języków, przybierające rozmaite formy i wymiary, a tematyce zagrożenia, wymierania, dokumentowania i tzw. rewitalizacji języków zagrożonych wymarciem poświęca się w ostat- 
nich latach coraz więcej projektów i programów działań, zarówno o charakterze lingwistycznym, jak i pozajęzykoznawczym ${ }^{1}$. Kierunek przeciwny to dające się zauważyć zwłaszcza w Europie tendencje do podnoszenia prestiżu odmian językowych, traktowanych wedle szerzej rozpowszechnionych opinii jako podrzędne w stosunku do uznanych języków (państwowych, narodowych, oficjalnych). Druga z zakreślonych tendencji - podnoszenie prestiżu dotychczas nieuznawanych etnolektów (przynajmniej w powszechniejszym zakresie) - tłumaczona bywa jako pochodna trendów „lokalizacyjnych” przeciwnych do tych globalizacyjnych na gruncie procesów socjolingwistycznych oraz językowo-politycznych (glottopolitycznych). Syntezę obu tych tendencji oraz ich skutki dla wykształcania nowych języków (w rozumieniu Ausbau Heinza Klossa - zob. dalej) Peter Trudgill (2004) określa jako „socjolingwistyczna glokalizację”.

Konfrontacji i w pewnym sensie ogólnej syntezie tych, zdawałoby się, przeciwstawnych tendencji przygląda się autor artykułu, szczególną uwagę zwracając na fenomen języków regionalnych w Europie.

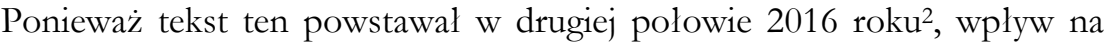
ówczesne poglądy i konstatacje autora miała szybko i radykalnie zmieniająca się w Europie i świecie waga narracji etnicznych i etniczno-językowych na poziomie lokalnym, regionalnym, narodowym i ogólnoeuropejskim. Należałoby zatem już w niedalekiej przyszłości przyjrzeć się badawczo wpływowi debat i szeroko rozumianych dyskursów publicznych, jawnych i niejawnych ideologii państw i społeczeństw narodowych, ich polityk historyczno-etnicznych na status, prestiż, postawy i ideologie językowe wewnątrz i w odniesieniu do autochtonicznych społeczności i języków mniejszościowych oraz regionalnych oraz poddać ten wpływ dogłębnej analizie. W typologiach socjolingwistycznych i glottopolitycznych konstelacji języków „mniej używanych" w Europie (np. Wicherkiewicz 2003; 2011) próbowano określić kryteria typowe dla tych (i kilku innych, jak np. zminoryzowane języki oficjalne, języki nieterytorialne, języki migowe, mikrojęzyki) sytuacji języko-

${ }^{1}$ Więcej na ten temat można znaleźć m.in. w kompendium Jezyyki w niebeąpieczeństwie dostępnym w rozmaitych wersjach językowych (np. http://pl.languagesindanger.eu), jak również w tomie: Olko, Wicherkiewicz, Borges 2016.

2 Z rozmaitych przyczyn, które określić można zbiorczo „splotem pechowych okoliczności”, tekst niniejszy nie znalazł się w tomie Polonistyka na poczatku XXI wieku. Diagnozy - koncepcje - perspektywy, t. 4. Pogranicza, mniejszości, regiony. Etnolingwistyka (Tambor 2018) [za co jako redaktorka tamtego tomu i współredaktorka niniejszego numeru „Postscriptum Polonistycznego" jeszcze raz Autora bardzo przepraszam - J.T.]. 
wych. Zdecydowana większość z nich, jak zwykle przy tego typu taksonomiach czy przyporządkowaniach, miała charakter pozajęzykowy.

\section{Języki Europy państw narodowych}

Często wciąż podtrzymywaną argumentacja pozalingwistyczną jest pozornie udowodniona wizja Europy jako stosunkowo spójnej, bo powielającej struktury polityczno-narodowe, administracyjne i nierzadko ideologiczne kompozycji języków (z rzadka urozmaicanej folklorystycznie barwiącymi ją pozostałościami odmian dialektalnych). W myśl narzucanego wciąż przez wiele agend rządowych, w tym i narodowe instytucje planowania językowego, postrzega się ustalone od dawna jednostki geopolityczne jako niezmienne i „ze swej natury" homogeniczne. Jednostki te - oparte na ideologicznych konstruktach Völker/Nationen autorstwa Johanna G. Herdera - były i są koncepcjami Wilhelma von Humboldta przenoszonymi na składniki (wizji) świata języków narodowych. Wizje takiego świata - początkowo w wymiarze europejskim, z czasem zaś wraz z kolonialną i postkolonialną ekspansją ideologii z politycznego centrum kontynentu na jego peryferie, a potem i cały glob - wzmocniła rewolucja francuska i jej idea oraz polityczna pragmatyka nation-état. Nałożenie się filozoficzno-językowych interpretacji świata według odziedziczonego po Wielkiej Rewolucji organicznego nacjonalizmu oraz nowożytnego językoznawstwa europejskiego - zwłaszcza ideologii językowej i etnolingwistycznej wizji świata Humboldta oraz teorii i praktyki hierarchizacji języków w postaci rozłącznych drzew genealogicznych Augusta Schleichera - stworzyło wyobrażenie poukładanego „raz na zawsze” repertuaru narodowych języków Europy i nieuporządkowanego świata języków „egzotycznych” poza nią.

To założenie skłaniać powinno językoznawców - zwłaszcza zajmujących się socjolingwistyką, polityką językową i tożsamością językową - do dokładniejszego przyjrzenia się szczególnej w praktyce europejskiej polityki językowej (o)pozycji języków: z jednej strony języków „narodowych”, z drugiej zaś odmian o statusie określanym jako wspomniane już wcześniej ,języki mniej/rzadziej używane" (obejmujących języki regionalne i regiolekty, dialekty i poddialekty, lekty w ogóle, narzecza, gwary, patois itp.).

Potrójna równoległość: langue $\leftrightarrow$ nation $\leftrightarrow$ état [ $\leftrightarrow$ langue (nationale)] kształtowała etnopolityczną i glottopolityczną historię nowożytnej Europy aż po 
schyłek XX wieku, pokrywając kontynent siatka granic polityczno-administracyjnych, które skutecznie zastępowały np. ważne w jej językowej historii wiązki izoglotyczne (np. linie: benracka, Uerdingen, Speyer, Joreta, Jirečka, skańsko-smalandžka i inne), a kontynualna rzeczywistość językowa została w ten sposób dopasowana do granic politycznych. Te uproszczenia geolingwistycznej struktury Europy przyczyniły się do zubożenia jej różnorodności językowej, nie tylko pod względem ilościowym, ale i jakościowym, skutkując osłabieniem potencjału wielu odmian językowych i przyspieszającym wzrostem stopnia zagrożenia języków na skalę dotąd w historii nienotowaną.

\section{Ausbausprache/Abstandsprache a Dachsprache}

Wydaje się, że problemu statusu językowego jakiejś odmiany nie da się w kontekście europejskim omawiać bez odniesień do modelu

Dachsprache

Ausbausprache

Abstandsprache

autorstwa Heinza Klossa (i Žarka Muljačića), zaproponowanego w celu możliwości socjolingwistycznej analizy i klasyfikacji statusu odmian językowych na pograniczu, pomimo dychotomicznego podziału na autonomiczne języki z jednej, a dialekty z drugiej strony. Zastosowana przez Klossa (1967; 1987) terminologia pokazywała dwa różne instrumentaria kryteriów i argumentów umożliwiających określenie statusu językowego: jedno oparte na funkcjach społecznych języka, drugie - na obiektywnych cechach strukturalnych/wewnątrzjęzykowych. Konieczne do zinterpretowania sytuacji obu pozostałych pojęcie Dachsprache wprowadził Muljačić (1986) w znaczeniu „języka parasolowego", czyli dominującego socjolingwistycznie nad występującymi na jego terytorium (pod jego „dachem”) odmianami językowymi. Ten ostatni jest językiem standardowym w odniesieniu do (grup) dialektów występujących zwykle w kontinuach, nawet gdy zróżnicowanie tych dialektów i ich dystans geolingwistyczny nie pozwala na wzajemną porozumiewalność. Dachsprache może stanowić obiekt planowania językowego, zwłaszcza gdy nowa, endogenna jego forma ma zastapić formę egzogenna. Ausbausprache znaczy ,język przez rozwój” i określa odmianę spokrewnioną ze swoją Dachsprache, która osiąnnęła status języka dzięki standaryzacji, jest nauczana w szkołach, używana jako język pisany w szerszym zakresie funkcji (poliwa- 
lencja funkcjonalna). Abstandsprache znaczy ,język przez dystans”, co charakteryzuje odmianę tak obiektywnie strukturalnie różną od Dachsprache, że nie może być ona uważana za jego dialekt. Kloss nie precyzował, jak ów dystans językowy mierzyć, aczkolwiek kryterium często przywoływanym była i jest (omawiana już wcześniej krytycznie) wzajemna porozumiewalność między użytkownikami dwóch odmian językowych. Kloss posługiwał się także pojęciem „dialektyzowanych pseudo-Abstandsprachen” w odniesieniu do odmian tak różnych od swoich Dachsprachen, iż winny być one traktowane jako odrębne języki „przez dystans” (Abstandsprache), jednak kontekst społeczny sprawia, iż są traktowane jak dialekty owych Dachsprachen - co w większości wypadków odpowiada sytuacji regionalnych języków kolateralnych.

\section{Języki regionalne w polskiej i europejskiej polityce językowej ${ }^{3}$}

W polskiej filologii pojęcie ,języka regionalnego” zostało użyte przez Alfreda Zarębę (1988), który potraktował je jako funkcjonalnie synonimiczne ze „(słowiańskimi) mikrojęzykami literackimi” Aleksandra M. Duliczenki (Ауличенко 1981; 1998), przeciwstawiając kryteriom, stosowanym przez tego ostatniego, cechy stanowiące o literackości języka, wyznaczone przez Aleksandra Isačenkę (1975) oraz Petera Rehdera (1984-1985):

1. Poliwalencję języka literackiego, tj. spełnianie wymogów językowego obsługiwania wszystkich zakresów komunikowania się w życiu narodu.

2. Występowanie normy we wszystkich płaszczyznach języka, tzn. w zakresie ortografii, wymowy, gramatyki i słownictwa.

3. Powszechność użycia języka przez wszystkich członków danej społeczności (zwykle, choć nie zawsze, narodowej).

4. Pełne zróżnicowanie stylistyczne (tzn. istnienie stylów funkcjonalnych).

Wymóg poliwalencji, o ile sam w sobie zrozumiały i akceptowalny, wykorzystuje w odniesieniu autorów pojęcie narodu, czym powraca do uzasadniającej funkcjonowanie języków retoryki, opartej na ideologii państwa narodowego. Jednak, jak się wydaje, „obsługiwanie wszystkich zakresów komu-

\footnotetext{
${ }^{3}$ Ten rozdział tekstu oparto w znacznej mierze na monografii Wicherkiewicz 2014.
} 
nikowania się w życiu narodu" w przypadku języków regionalnych nie jest nawet warunkiem koniecznym ich rozwoju i funkcjonowania w formie języka literackiego czy ogólnego, jako że ex definitione wiele owych zakresów obsługiwanych jest przez dominującą Dachsprache. Wymóg występowania normy we wszystkich płaszczyznach języka jest również niejako antynomiczny dla charakteru wielu mniejszościowych języków Europy w ogóle, które funkcjonuja jako kontynualne zespoły dialektów i adaptowana dla nich ortografia ma siłą rzeczy umożliwiać zapis form dialektalnych i interdialektalnych. Zauważyć jeszcze koniecznie należy, iż przeszkodą w spełnieniu zakreślonych wymogów przez mikrojęzyki jest oczywisty zespół faktów pozajęzykowych wynikających $\mathrm{z}$ ich funkcjonowania w obrębie struktur polityczno-narodowych innych języków (Dachsprachen).

Skonfrontowane z ustaleniami Aleksandra Isaczenki i Petera Rehdera kryteria Aleksandra Duliczenki (oraz z sytuacją regionalnych i mniejszościowych języków Włoch) Alfred Zaręba spróbował zastosować do odmian regionalnych w Polsce: kaszubszczyzny czy laszczyzny. Poza kryteriami naukowymi Zaręba obracał się jednak bezustannie w kręgu terminologii „narodowej” i odniesień do niej (w postaci „niepokojów” o status dialektów laskich czy przytaczanych przy okazji statusu językowego kaszubszczyzny prób „utworzenia przez hitlerowców tzw. Goralenvolke”). Przez długi okres zwłaszcza II połowy XX wieku - takie właśnie obawy i nierozerwalne kojarzenie kryteriów językowych z narodowymi oraz nierozróżnianie polityki językowej i narodowościowej uniemożliwiały wspólnotom języków regionalnych podwyższenie prestiżu i statusu swoich języków.

Jak dywagował kasandrycznie Zaręba:

Można sobie oczywiście wyobrazić, że Kaszubi upomną się o swoją szkołę i urzędy kaszubskie, ale nawet gdyby do tego doszło, w co wątpię, to przegrają w konkurencji z językiem polskim, który jest językiem państwowym na całym obszarze Polski (nie mówiąc o wielkich skupiskach polonijnych rozsianych po całym świecie)... (Zaręba 1988, 86),

wieszcząc następnie kaszubszczyźnie nieuniknioną klęskę wzorem języków łużyckich, które - jak twierdził - wprowadzano do szkół i oficjalnego (jak dziś rzeklibyśmy) pejzażu językowego regionu wbrew życzeniom samych Łużyczan.

Taki sam wynik i los przewidywałbym dla kaszubszczyzny, jak i łużycczyzny, co nie znaczy, że nie doceniam głęboko w sercach Kaszubów 
tkwiącej miłości do swojej mowy (...). Tak więc gdziekolwiek na świecie przejawi się tendencja czy bodaj iskierka powrotu do języka, mowy swoich przodków (...) wszędzie są to godne uznania i szacunku zjawiska, jako fakty przywiązania do swoich korzeni. Nie znaczy to jednak, że wszędzie powstaną tzw. mikrojęzyki literackie (Zaręba 1988, 86).

Wymowa tekstu Zaręby pokazuje, jak znaczne zmiany dokonały się w metodologii, terminologii, ale przede wszystkim w nastawieniu do problematyki nowych języków, gdy skonfrontuje się ją z pracami Gerda Hentschela (np. 2003). Co prawda niemiecki badacz określa w nich przedmiot swoich rozważań tytułowym mianem „new minor Abstandsprachen”, co może budzić wątpliwości w porównaniu z pierwotnymi definicjami Abstand/Ausbau, jednak analiza Klossowskich i Duliczenkowskich kryteriów pozwala bez charakterystycznych dla Zaręby obaw (o wiele trafniej, jak się okazuje) zbadać możliwości i perspektywy rozwoju kaszubszczyzny, śląszczyzny i podhalańszczyzny, dodatkowo także w kontekście kryterium przez innych specjalistów pomijanego, a mianowicie: przerwanego kontinuum językowego obszaru języka polskiego jako Dachsprache. Choć mowa tu o peryferyjnych wszak odmianach, które są owego przerwanego kontinuum pozostałościami. Spostrzeżenia Hentschela uzupełnić można też konstatacja, iż to właśnie te odmiany brały najmniejszy (jeśli w ogóle) udział w konstruowaniu systemu i statusu standardowej polszczyzny, stanowiącej obecnie dla nich socjolingwistyczną i glottopolityczną Dachsprache.

Analiza glottopolitycznego rozwoju i współczesnej socjolingwistycznej sytuacji kaszubszczyzny i innych języków regionalnych - też w kontekście ekolingwistycznej żywotności - pozwala zweryfikować pozanaukowe obawy i wyroki ferowane przez Zarębę. Dość stwierdzić, że „tzw. mikrojęzyki literackie" istotnie nie powstały wszędzie, natomiast językowy krajobraz Europy ujawnił, a prawodawstwo europejskie uwzględniło fenomen ,języków regionalnych".

W ciagu ponad dwóch lat od powstania tego tekstu opublikowano wiele istotnych pozycji dotyczących języków regionalnych - jednak na szczególna uwage zasługuje tom zbiorowy Sterna, Nomachiego i Belicia (Stern, Nomachi, Belić 2018), z monograficznymi rozdziałami poświęconymi m.in. (mikro)językom regionalnym: buniewskiemu i banacko-bułgarskiemu, laskiemu, limburskiemu, lombardzkiemu i sycylijskiemu, łemkowskiemu, mirandyjskiemu, morawskiemu, podlaskiemu, pomackiemu, wschodniosłowackiemu.

Nowego zaś, skodyfikowanego prawnie i klasyfikacyjnego znaczenia termin „język regionalny” nabrał w języku polskim postanowieniem Ustawy o mniej- 
szościach narodowych $i$ etnicznych oraz o jezylku regionalnym. Ten akt prawny w art. 19, w punkcie 1. podaje:

Za język regionalny w rozumieniu ustawy, zgodnie z Europejska karta jezykón regionalnych lub mniejszościowych, uważa się język, który:

1) jest tradycyjnie używany na terytorium danego państwa przez jego obywateli, którzy stanowią grupę liczebnie mniejszą od reszty ludności tego państwa;

2) różni się od oficjalnego języka tego państwa; nie obejmuje to ani dialektów oficjalnego języka państwa, ani języków migrantów.

W punkcie 2. wskazuje, że „[j]ęzykiem regionalnym w rozumieniu ustawy jest język kaszubski”.

Dyskusyjny jest oczywiście sam tok myślenia ustawodawcy, który wpierw stara się zdefiniować termin, później zaś explicite (jakby sama definicja była nie dość jasna) podaje sam podmiot tego fragmentu ustawy.

Trzeba też zauważyć, że „rozumienie ustawy” wcale nie jest jednoznacznie zgodne z Europejska karta jezylków regionalnych lub mniejszościonych [EKJRM], gdyż konwencja ta nie rozróżnia tytułowych ,języków regionalnych” od „mniejszościowych”, a zatem cytowana uprzednio definicja z Ustawy w Karcie odnosi się praktycznie do wszystkich mniejszościowych języków autochtonicznych.

Pierwszym państwem, które usankcjonowało w ratyfikowanej przez siebie wersji EKJRM rozróżnienie między dwiema tytułowymi sytuacjami języków, była Republika Federalna Niemiec. W 1999 roku, po szerokiej dyskusji, kraje związkowe północnych Niemiec uznały język dolnoniemiecki (Niederdeutsch) za chroniony i promowany Karta Regionalsprache; w odróżnieniu od uznanych za Minderheitensprachen języków łużyckich, fryzyjskich, duńskiego oraz nieterytorialnych jidysz i romani. Owa pragmatyczno-prawna dychotomia przyjęta w Republice Federalnej Niemiec, z uwzględnieniem lokalnych tradycji terminologicznych, stała się precedensem, do którego później odniósł się polski ustawodawca, szukając ustawowej klasyfikacji dla kaszubszczyzny, znajdującej się w sytuacji zbliżonej pod względem socjolingwistycznym do dolnoniemieckiego. Tym samym i pojęcie, i fakt ochrony języków regionalnych stały się bezpośrednim rezultatem inicjatyw europrawnych. Kolejnym, uznanym oficjalnie językiem regionalnym miał stać się również limburski: Królestwo Niderlandów włączyło go do inwentarza języków chronionych EKJRM podczas powtórnego procesu ratyfikacyjnego. 
W trakcie dyskusji nad włączeniem dolnoniemieckiego do EKJRM argumentowano, że dla języków regionalnych wyznacznikiem jest przede wszystkim ich terytorium. Choć ich użytkownicy mówią językami mniej lub bardziej typologicznie odmiennymi od standardowego języka państwa, na którego terenie mieszkają, nie postrzegają swojej narodowej odrębności od reszty populacji.

Casus dolnoniemieckiego w Niemczech i kaszubskiego w Polsce przywoływane są często w staraniach czy żądaniach uznania bądź w krajowym systemie prawnym, bądź w przygotowywanych przez poszczególne państwa do ratyfikacji wersjach EKJRM walońskiego i innych języków: oïl w Belgii, lombardzkiego i piemonckiego we Włoszech, łatgalskiego na Łotwie i żmudzkiego na Litwie, języka võro (często jako võro-seto) w Estonii, czy megrelskiego i swańskiego w Gruzji.

Zastanawiając się nad etnicznym odniesieniem dychotomii ,język” - ,język regionalny", odwołać się można do stosowanego w etnologii rozróżnienia między terminami „naród” i „narodowość”, gdzie ten drugi oznacza regionalną wspólnotę kulturowo-językową, będącą - lub traktowaną za - przednarodową formę integracji etnicznej. W polskim ustawodawstwie przyjęto w tym znaczeniu stosowanie - choć niekonsekwentnie - pojęcia „grupy etnicznej”, czyli grupy nieidentyfikującej się ze zorganizowanym w inne państwo narodem, czy też „grupy narodowościowej” (Posern-Zieliński 2005; Šatava 2006).

$\mathrm{Na}$ gruncie socjolingwistyki i polityki językowej najwłaściwsze wydaje się zastosowanie na tym samym poziomie właśnie terminu ,język regionalny” oznaczającego odmianę takiej właśnie grupy, znajdującej się w procesach etnicznych in statu nascendi, której standard językowy - stanowiący podstawowy łącznik wewnątrzgrupowy - również znajduje się na etapie pomiędzy zespołem dość luźnych, choć powiązanych właśnie tożsamością regionalną bardziej niż etniczna, dialektów. Tak jak ze słabo spojonych grup regionalnych /etnograficznych tworzy się grupa etniczna, a dalej i narodowość (w oficjalnej terminologii dotyczącej np. żmudzkiego na Litwie pojawiło się nawet pojęcie „subnarodu”), tak z zespołu dialektów powstaje język regionalny. To terminologiczny, ustawodawczy i oczywiście ogólnopolityczny termin pozwalający wypełnić pustkę pomiędzy wymierającymi dialektami a rodzącymi się językami. W monografii na temat tego typu języków autor (Wicherkiewicz 2014) zaproponował rozszerzenie pojęcia do modelu regionalnych jezy ków kolateralnych.

Zespół zatem cech geolingwistycznych, historycznojęzykowych, socjolingwistycznych, etnolingwistycznych i pozajęzykowych glottopolitycznych, które charakteryzują ów model, obejmować winien następujące kryteria: 
- endogenność i autochtoniczność - rdzenność języka na jego terytorium, aczkolwiek - jak wynika z dziejów poszczególnych języków kolateralnych - dochodzić mogło i dochodziło do przesunięć na tych terytoriach;

- (regionalna) terytorialność wynikająca z poprzedniego kryterium jako jednego z podstawowych czynników identyfikacyjnych wspólnoty językowej, pozbawionej (przez ekspansję zewnętrznych etnosów dominujących lub w wyniku braku czynnika narodotwórczego w dziejach wspólnoty) odwołań do terytorium narodowo-państwowego;

- bliska odległość językowa i niedalekie pokrewieństwo genetyczne z dominującym językiem większości, najczęściej tytularnym językiem nation-état, funkcjonującym jako Dachsprache;

- wspólna na pewnych etapach historia rozwoju (równoległego, stąd „kolateralność”) języka kolateralnego z dominującym;

- peryferyjne położenie terytorium języka kolateralnego w stosunku do terytorium języka ogólnonarodowego, dominującego jako Dachsprache;

- przeważająca rola czynników typu Ausbau jako dyferencyjnych lub dyferencjujących w stosunku do Dachsprache;

- często wyższy status i prestiż języka kolateralnego w przeszłości, np. jako języka międzyetnicznego, tworzywa i nośnika kultury wysokiej, języka (współ)oficjalnego; późniejsza degradacja prestiżu języka i postrzeganie go jako wiejskiego, niewykształconego, patois, mieszanego, „zepsutego”, ,skorodowanego”;

- standaryzacja, kodyfikacja i normalizacja na etapie in statu (re)nascendi zwykle zapoczątkowana w (odleglejszej) przeszłości dziejów języka, natomiast zintensyfikowana ponownie pod koniec XX wieku, zwykle na skutek działań rewitalizacyjnych na rzecz języka;

- funkcjonowanie w postaci kontynualnych zespołów dialektów, stanowiących odniesienie (sub)tożsamości regionalnych i często konkurencyjnych z socjolingwistycznej i glottopolitycznej perspektywy wobec upowszechnianej normy literackiej;

- powszechna dyglosja z dominującą Dachsprache;

- brak lub znikome poczucie odrębności narodow(ościow)ej, opór przeciwko statusowi mniejszości (narodowej) - w zamian możliwa tożsamość podwójna, „zanurzona”, „nadbudowana” wobec narodu dominującego oraz poszukiwanie w zamian terminologicznych substytutów, jak „subnaród”, „społeczność regionalna” i inne; 
- silne poczucie tożsamości regionalnej, przekładającej się na identyfikację z dialektem/grupą dialektów w stopniu często wyższym niż z całym kolateralnym kompleksem językowym.

Budowa statusu języka regionalnego to często działanie uzupełniające bądź nawet zastępujące brak działań państw (szczególnie państw europejskich) wspierających rozwój tożsamości etnicznej/regionalnej, w tym językowej na rzecz tych części swojego terytorium, które pomimo historycznych zawirowań, leżąc na peryferiach tych państw, aktywnie uczestniczyły w budowie kultury, tożsamości nie tylko regionalnej, ale i ponadregionalnej, ogólnonarodowej. Gdy instytucje i ideologia państwa scentralizowanego, skupionego na konsolidowaniu wszelkich sił i wartości jedynie wokół centrum i wartości przezeń wyrażanych, ignorują postponują, odsuwają na dalszy plan aspiracje wskazanych części, pojawiają się ruchy regionalne. Te zaś, dzięki europejskim instrumentom prawnym, przybieraja postać wspólnot budujących i posługujących się językami regionalnymi i wykorzystując współczesne mechanizmy polityki językowej oraz metody planowania językowego, wzbogacają niknącą rozmaitość języków Europy o nowe języki regionalne. Z perspektywy lingwistycznych transdyscyplin badających i opisujących procesy utrzymania, zanikania i rewitalizacji języków, wspólnoty te i ich symboliczne „nowe języki” przypominaja już wtedy wszystkie inne języki mniejszościowe i ich konstelacje.

Konkluzją niniejszego tekstu niech będzie konstatacja, że - w opinii piszącego - to właśnie posługujące się rozmaitymi instrumentami planowania językowego regionalne społeczności/odmiany języków kolateralnych typu Ausbau wypełniają ekolingwistyczną pustkę po z(a)nikających językach typu Abstand...

\section{Literatura}

Hentschel G., 2003, New minor Abstandsprachen under the roof of a genetically close literary language?

The case of Polish us. Kashubian, Silesian and Podhalan, in: Sherzer J., Stolz T., red., Minor Languages - Approaches, Definitions, Controversies, Bochum.

Isačenko A.V., 1975, Mythen und Tatsachen über die Entstehung der russischen Literatursprache, Wien. Kloss H., 1967, Abstand Languages and Ausbau Languages, "Anthropological Linguistics”, no. 9

(7).

Kloss H., 1987, Abstandsprache und Ausbausprache, in: Ammon U., Dittmar N., Mattheier K.J., red, Sociolinguistics/Soziolinguistik. An International Handbook of the Science of Language and Society/Ein internationals Handbuch zur Wissenschaft von Sprache und Gesellschaft, t. I, Berlin/New York. 
Muljačić Ž., 1986, L'enseignement de Heinz Kloss (modifications, implications, perspectives), "Langages", no. 21.

Olko J., Wicherkiewicz T., Borges R., red., 2016, Integral Strategies for Language Revitalization, Warsaw.

Posern-Zieliński A., 2005, Etniczność. Kategorie. Procesy etniczne, Poznań.

Rehder P., 1984-1985, Slavische Mikroliteratursprachen?, „Zbornik Matice Srpske za filologiju i lingvistiku", no. XXVII-XXVIII.

Šatava L., 2006, „Regionální jasyky”” jako emancipační strategie (latgalština a võro-seto - dva přklady z Pobaltí), „Ethnologia Actualis Slovaca”, č. 6.

Stern D., Nomachi M., Belić B., 2018, ed., Linguistic Regionalism in Eastern Europe and Beyond. Minority, Regional and Literary Microlanguages, Frankfurt am Main, https://biblio. ugent.be/publication/8578486/file/8578487.pdf [dostęp: 20.12.2018].

Tambor J., 2018, red., Polonistyka na poczatku XXI wieku. Diagnozy - koncepcje-perspektywy, t. 4, Pogranicza, mniejszości, regiony. Etnolingwistyka, Katowice.

Trudgill P., 2004, Glocalization and the Ausbau sociolinguistics of modern Europe, in: Duszak A., Okulska U., ed., Speaking from the margin: global English from a European perspective, Frankfurt am Main.

Wicherkiewicz T., 2003, Jezykei mniejszościowe i regionalne w Europie - problemy typologii, w: Wrocławska E., Zieniukowa J., red., Jezyłki mniejszości i jezykei regionalne, Warszawa.

Wicherkiewicz T., 2011, Jezyki regionalne w Europie Środkowo-W schodniej - nowa jakość w polityce jezykowej, nowy wymiar tożsamości, „Język. Komunikacja. Informacja”, t. 6, Polityka jezylkowa $w$ Europie Środkowo-W schodniej.

Wicherkiewicz T., 2014, Regionalne jezyki kolateralne Europy - porównawcze studia przypadku z.polityki jezykowej, Poznań.

Zaręba A., 1988, Literackie jezykei regionalne w Polsce?, „Język Polski”, nr LXVIII.

Ауличенко А.А., 1981, Славянские литературные микроязыки, Тамлин.

Ауличенко А.А., 1998, Языки малых этнических групп: Статус, развитие, проблемь выљивания, в: Языки малье и большие... in mетоriam acad. Nikita I. Tolstoi, Тарту. 